\title{
Erratum to: Antibiotics and Antibiotics Resistance Genes in Soils
}

\author{
Monitoring, Toxicity, Risk Assessment \\ and Management
}

Muhammad Zaffar Hashmi, Vladimir Strezov, and Ajit Varma

\author{
Erratum to: \\ M.Z. Hashmi et al. (eds.), Antibiotics and Antibiotics Resistance \\ Genes in Soils, Soil Biology 51, \\ DOI: 10.1007/978-3-319-66260-2
}

\footnotetext{
The updated online versions of these chapters can be found at DOI: $10.1007 / 978-3-319-66260-2 \_3$ DOI: $10.1007 / 978-3-319-66260-2 \_4$ DOI: $10.1007 / 978-3-319-66260-2 \_5$ DOI: $10.1007 / 978-3-319-66260-2 \_6$ DOI: $10.1007 / 978-3-319-66260-2 \_7$ DOI: $10.1007 / 978-3-319-66260-2 \_8$ DOI: $10.1007 / 978-3-319-66260-2 \_9$ DOI: $10.1007 / 978-3-319-66260-2 \_10$ DOI: $10.1007 / 978-3-319-66260-2 \_11$ DOI: $10.1007 / 978-3-319-66260-2 \_12$ DOI: $10.1007 / 978-3-319-66260-2 \_13$ DOI: $10.1007 / 978-3-319-66260-2 \_14$ DOI: $10.1007 / 978-3-319-66260-2 \_15$ DOI: $10.1007 / 978-3-319-66260-2 \_16$ DOI: $10.1007 / 978-3-319-66260-2 \_17$ DOI: $10.1007 / 978-3-319-66260-2 \_18$ DOI: $10.1007 / 978-3-319-66260-2 \_19$ DOI: $10.1007 / 978-3-319-66260-2 \_20$ DOI: $10.1007 / 978-3-319-66260-2 \_21$ DOI: $10.1007 / 978-3-319-66260-2$
} 
The original version of this book contains errors which have been corrected. The corrections are given below:

Chapter 3: A Review on Antibiotics Consumption, Physico-Chemical Properties and Their Sources in Asian Soil

The contents of the following sub-headings have been updated:

1) Abstract

2) 3.1 Introduction

3) 3.2 Antibiotics: How Does It Work?

4) 3.3.2 Livestock and Agricultural Usage

5) 3.4.1 Tetracycline and Sulfonamides

6) 3.4.2 Fluoroquinolones

7) 3.4.3 Macrolides

8) 3.4.4 Aminoglycoside

9) 3.5 Sources of Antibiotics in Asian Soil

10) 3.6 Occurrence of antibiotics in Asian soil

The following subheadings and their contents have been added to the chapter:

\subsection{Occurrence of Antibiotics in Asian Soil}

From the sources discussed previously in this chapter, it is evident that antibiotics can end up in the soil, and finally via plant uptake, such chemicals may enter the food chain. Despite such existing sources, limited data is available on the level of antibiotics in Asian soil. Antibiotic levels in soil in China and Korea among Asian countries have been given in Table 3.5. All the tetracycline compounds showed highest range in Shenyang region, China. Agriculture, animal husbandry, and agricultural product processing units were dominant in north-eastern part of Shenyang city. Sulfonamide compounds also showed very high concentration in Shenyang city. Sulfonamides and tetracycline are the two antibiotics most commonly used to promote growth in livestock production. So it is evident that the high concentration of these two compounds in Shenyang city is due to the use of these two antibiotics in livestock production. As compared to China, the antibiotic concentration in Korean soil is less. This may be because, since 2005, South Korea is gradually decreasing the use of antibiotic growth promoters in livestock production. 


\subsection{Conclusion}

Like several other organic pollutants, anitibiotics also reach soil mostly after partially treated or untreated antibiotics present in wastewater stream. Studies across the globe have reported the uptake of antibiotics by plants. The pathway of these pollutants generally depends on its physio-chemical properties. Studies have shown the development of antibiotic resistance genes in soil, plants, and humans. Further studies are required to find the fate of these pollutants in the environment and the associated risk due to the occurrence of these antibiotics in the environment.

The following tables have been added to the chapter: 


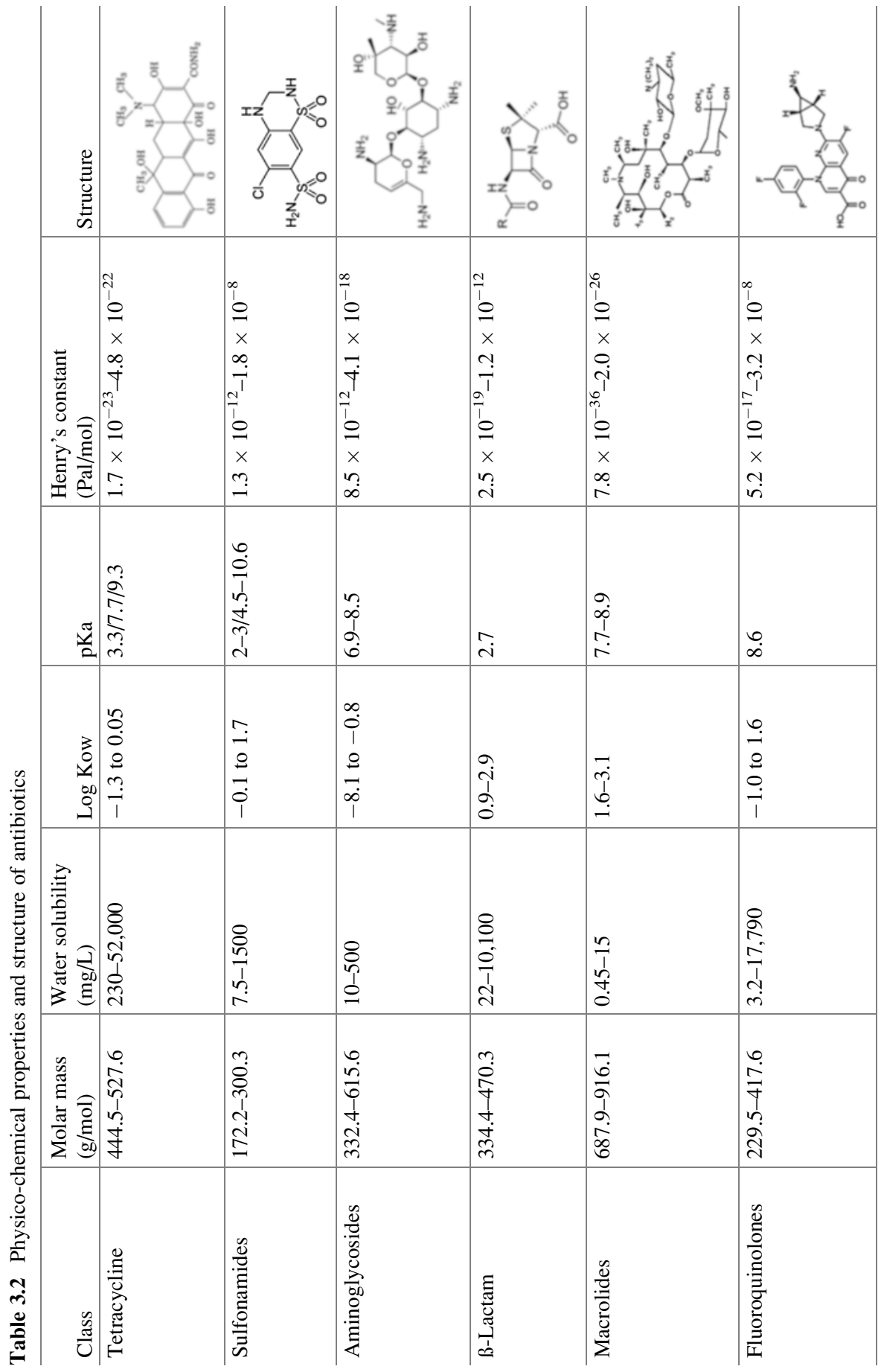


Table 3.3 Antibiotics in the sludge from wastewater treatment plant used as manure

\begin{tabular}{|c|c|c|c|}
\hline Compounds & Sludge $(\mu \mathrm{g} / \mathrm{g})$ & Country & Reference \\
\hline \multicolumn{4}{|l|}{ Tetracycline } \\
\hline Tetracycline & 2174.46 & Sheyang, China(NE) & An et al. (2015) \\
\hline Oxytetracycline & 7369.67 & Sheyang, China(NE) & An et al. (2015) \\
\hline Chlortetracycline & 3843.79 & Sheyang, China(NE) & An et al. (2015) \\
\hline Doxycycline & 2104.27 & Sheyang, China(NE) & An et al. (2015) \\
\hline \multicolumn{4}{|l|}{ Sulfonamides } \\
\hline Sulfamethoxazole & 665 & Sheyang, China(NE) & An et al. (2015) \\
\hline Sulfadiazine & 50.32 & Sheyang, China(NE) & An et al. (2015) \\
\hline Sulfamerazine & 37.21 & Sheyang, China(NE) & An et al. (2015) \\
\hline Sulfadimidine & 27.14 & Sheyang, China(NE) & An et al. (2015) \\
\hline
\end{tabular}

Table 3.4 Antibiotics from livestock excreta used as manure

\begin{tabular}{|c|c|c|c|}
\hline Compounds & $\begin{array}{l}\text { Livestock } \\
\text { manure (mg/g) }\end{array}$ & Country & Reference \\
\hline \multicolumn{4}{|l|}{ Tetracycline } \\
\hline \multirow[t]{3}{*}{ Tetracycline } & 56.95 & Sheyang, China(NE) & An et al. (2015) \\
\hline & 43.5 & North China & Hu et al. (2010) \\
\hline & 3.5 & Beijing & Li et al. (2015) \\
\hline \multirow[t]{3}{*}{ Oxytetracycline } & 47.25 & Sheyang, China(NE) & An et al. (2015) \\
\hline & 183.5 & North China & Hu et al. (2010) \\
\hline & 23.271 & Beijing & Li et al. (2015) \\
\hline \multirow[t]{3}{*}{ Chlortetracycline } & 143.97 & Sheyang, China(NE) & An et al. (2015) \\
\hline & 26.8 & North China & Hu et al. (2010) \\
\hline & 26.218 & Beijing & Li et al. (2015) \\
\hline Doxycycline & 6.5 & Sheyang, China(NE) & An et al. (2015) \\
\hline \multicolumn{4}{|l|}{ Fluoroquinolones } \\
\hline Enrofloxacin & 8.684 & Beijing & Li et al. (2015) \\
\hline \multirow[t]{2}{*}{ Ciprofloxacin } & 4.3 & North China & Hu et al. (2010) \\
\hline & 9.342 & Beijing & Li et al. (2015) \\
\hline Norfloxacin & 4.187 & Beijing & Li et al. (2015) \\
\hline Ofloxacin & 15.7 & North China & Hu et al. (2010) \\
\hline Perfloxacin & 24.7 & North China & Hu et al. (2010) \\
\hline Lomefloxacin & 0.038 & Beijing & Li et al. (2015) \\
\hline \multicolumn{4}{|l|}{ Macrolide } \\
\hline Roxithromycin & 0.067 & Beijing & Li et al. (2015) \\
\hline Lincomycin & 3.8 & North China & Hu et al. (2010) \\
\hline \multicolumn{4}{|l|}{ Sulfonamides } \\
\hline \multirow[t]{3}{*}{ Sulfamethoxazole } & 18.5 & Sheyang, China(NE) & An et al. (2015) \\
\hline & 5.7 & North China & Hu et al. (2010) \\
\hline & 0.102 & Beijing & Li et al. (2015) \\
\hline
\end{tabular}


Table 3.4 (continued)

\begin{tabular}{l|l|l|l}
\hline \multirow{2}{*}{ Compounds } & $\begin{array}{l}\text { Livestock } \\
\text { manure }(\mathrm{mg} / \mathrm{g})\end{array}$ & Country & Reference \\
\hline \multirow{2}{*}{ Sulfadiazine } & 4.98 & Sheyang, China(NE) & An et al. (2015) \\
\cline { 2 - 4 } & 0.022 & Beijing & Li et al. (2015) \\
\hline Sulfamerazine & 4.59 & Sheyang, China(NE) & An et al. (2015) \\
\hline Sulfadimidine & 1.95 & Sheyang, China(NE) & An et al. (2015) \\
\hline Sulfamethazine & 0.061 & Beijing & Li et al. (2015) \\
\hline Sulfadoxin & 32.7 & North China & Hu et al. (2010) \\
\hline Sulfachloropyridazine & 2.76 & North China & Hu et al. (2010) \\
\hline
\end{tabular}

Table 3.5 Wastewater containing antibiotics used for irrigation

\begin{tabular}{|c|c|c|c|}
\hline Compounds & Wastewater (ng/l) & Country & Reference \\
\hline \multicolumn{4}{|l|}{ Tetracycline } \\
\hline \multirow[t]{2}{*}{ Tetracycline } & 560 & New York & Batt et al. (2006) \\
\hline & 48,000 & Wisconsin, USA & Karthikeyan et al. (2006) \\
\hline Oxytetracycline & 47,000 & Wisconsin, USA & Karthikeyan et al. (2006) \\
\hline \multicolumn{4}{|l|}{ Fluoroquinolones } \\
\hline Enrofloxacin & 250 & Wisconsin, USA & Karthikeyan et al. (2006) \\
\hline \multirow[t]{3}{*}{ Ciprofloxacin } & 10 & USA & He et al. (2015) \\
\hline & 970 & New York & Batt et al. (2006) \\
\hline & 310 & Wisconsin, USA & Karthikeyan et al. (2006) \\
\hline Norfloxacin & 250 & Wisconsin, USA & Karthikeyan et al. (2006) \\
\hline Ofloxacin & 9 & USA & He et al. (2015) \\
\hline \multicolumn{4}{|l|}{ Macrolide } \\
\hline Erithromycin & 3900 & Wisconsin, USA & Karthikeyan et al. (2006) \\
\hline Roxithromycin & 1500 & Wisconsin, USA & Karthikeyan et al. (2006) \\
\hline \multicolumn{4}{|l|}{ Salfonamides } \\
\hline \multirow[t]{3}{*}{ Sulfamethoxazol } & 156 & South Africa & Rahzia et al. (2012) \\
\hline & 1340 & New York & Batt et al. (2006) \\
\hline & 310 & Wisconsin, USA & Karthikeyan et al. (2006) \\
\hline \multirow[t]{2}{*}{ Sulfamethazine } & 50 & China & Sun et al. (2014) \\
\hline & 300 & Wisconsin, USA & Karthikeyan et al. (2006) \\
\hline
\end{tabular}




\section{The following Figures have been updated:}

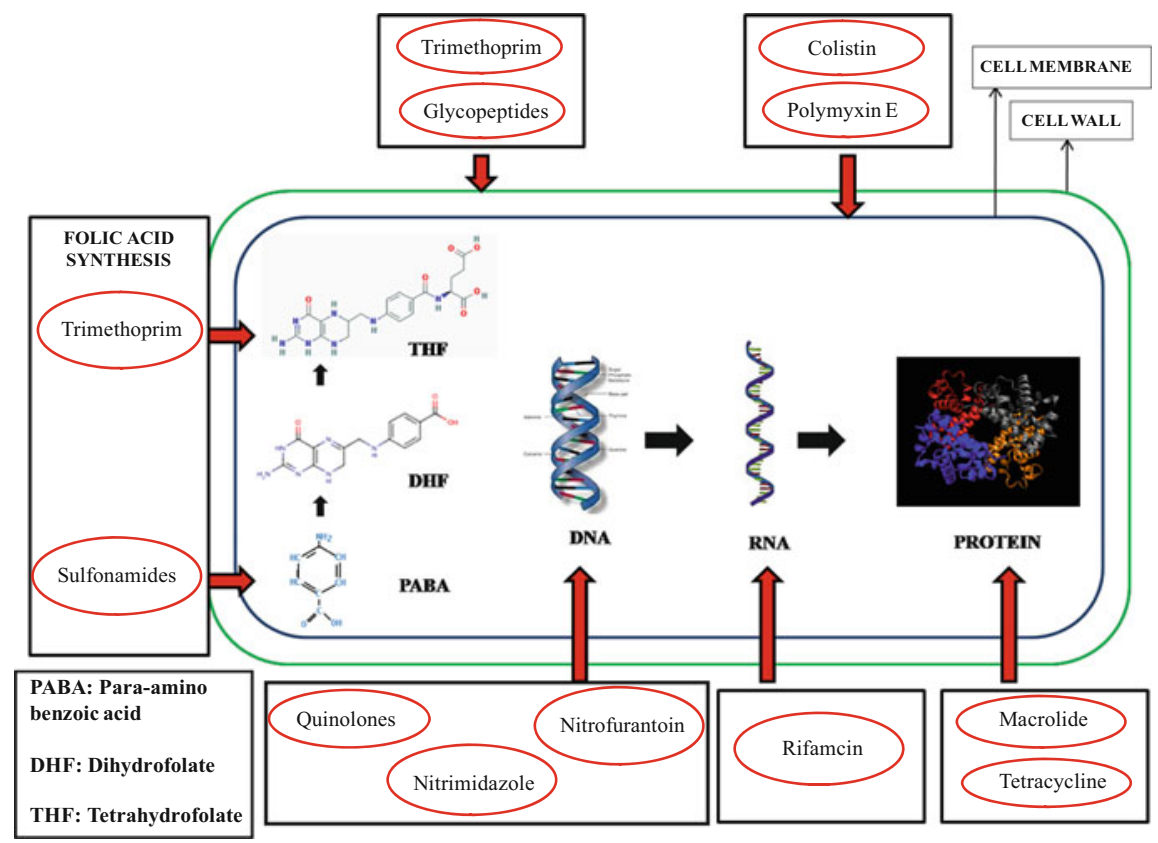

Fig. 3.1 Hypothetical schematic representation showing the mode of action of different antibiotics against bacteria

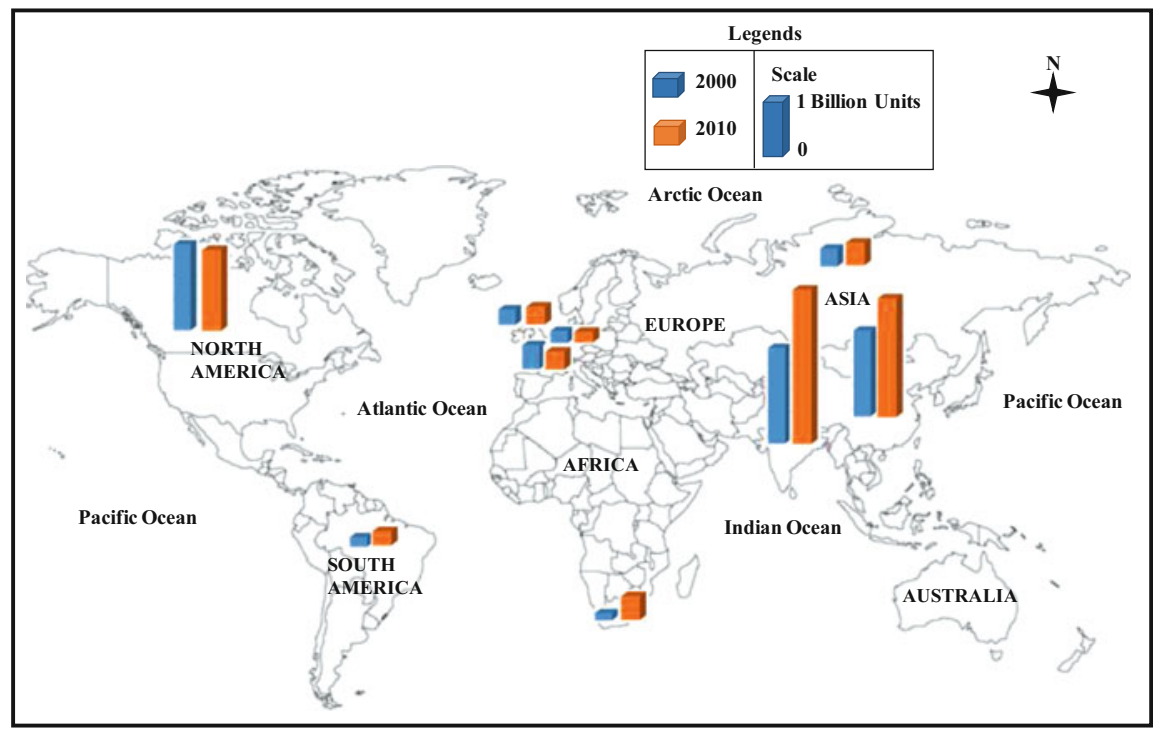

Fig. 3.2 Consumption of antibiotics by different countries across the globe during 2000 and 2010 . (Data courtesy-Van Boeckel et al. 2015) 


\section{The following References have been added to the chapter:}

An J, Chen H, Wei S, Gu J (2015) Antibiotic contamination in animal manure, soil, and sewage sludge in Shenyang, northeast China. Environ Earth Sci 74 (6):5077-5086

Awad YM, Kim S-C, Abd El-Azeem SAM, Kim K-H, Kim K-R, Kim K, Jeon C, Lee SS, Ok YS (2014) Veterinary antibiotics contamination in water, sediment, and soil near a swine manure composting facility. Environ Earth Sci 71(3):1433-1440

Bbosa GS, Mwebaza N (2013) Global irrational antibiotics/antibacterial drugs use: a current and futurehealth and environmental consequences. Microbial pathogens and strategies for combating them: science,technology and education. Formatex, Badajoz

Bound JP, Voulvoulis P (2004) Pharmaceuticals in the aquatic environment - a comparison of risk assessment strategies. Chemosphere 56:1143-1155.

Chen F, Ying G-G, Kong L-X, Wang L, Zhao J-L, Zhou L-J, Zhang L-J (2011) Distribution and accumulation of endocrine-disrupting chemicals and pharmaceuticals in wastewater irrigated soils in Hebei, China. Environ Pollut 159 (6):1490-1498

Defoirdt T, Sorgeloos P, Bossier P (2011) Alternatives to antibiotics for the control of bacterial disease in aquaculture. Curr Opin Microbiol 14(3):251-258

Fatta-Kassinos D, Meric S, Nikolaou A (2011) Pharmaceutical residues in environmental waters and wastewater: current state of knowledge and future research. Anal Bioanal Chem 1:251-275

Gao P, Mao D, Luo Y, Wang L, Xu B, Xu L (2012) Occurrence of sulfonamide and tetracycline-resistant bacteria and resistance genes in aquaculture environment. Water Res 46(7):2355-2364

Ghosh K, Mandal S (2010) Antibiotic resistant bacteria in consumable fishes from Digha coast, West Bengal, India. Proc Zool Soc 63(1):13-20

Heberer T (2002) Occurrence, fate, and removal of pharmaceutical residues in the aquatic environment: a review of recent research data. Toxicol Lett 131 $(1-2): 5-17$

Hu X, Luo Y, Zhou Q (2010) Simultaneous analysis of selected typical antibiotics in manure by microwave assisted extraction and LC-MS. Chromatographia 71:217-223

Hu X, Zhou Q, Luo Y (2010) Occurrence and source analysis of typical veterinary antibiotics in manure, soil, vegetables and groundwater from organic vegetable bases, northern China. Environ Pollut 158(9):2992-2998

Kim S-C, Carlson K (2007) Temporal and spatial trends in the occurrence of human and veterinary antibiotics in aqueous and river sediment matrices. Environ Sci Technol 41:50-57

Kim S-C, Carlson K (2007) Temporal and spatial trends in the occurrence of human and veterinary antibiotics in aqueous and river sediment matrices. Environ Sci Technol 41:50-57 
Kinney CA, Furlong ET, Werner SL, Cahill JD (2006) Presence and distribution of wastewater-derived pharmaceuticals in soil irrigated with reclaimed water. Environ Chem 25:317-325

Kinney CA, Furlong ET, Werner SL, Cahill JD (2006) Presence and distribution of wastewater-derived pharmaceuticals in soil irrigated with reclaimed water. Environ Toxicol Chem 25(2):317

Kummerer K, Henniger A (2003) Promoting resistance by the emission of antibiotics from hospitals and households into effluent. Clin Microbiol Infect 9:1203-14

Kwon SI, Owens G, Ok YS, Lee DB, Jeon W-T, Kim JG, Kim K-R (2011) Applicability of the Charm II system for monitoring antibiotic residues in manurebased composts. Waste Manag 31(1):39-44

Li B, Zhang T (2011) Mass flow and removal of antibiotics in two municipal wastewater treatment plants. Chemosphere 831284-1289

Li C, Chen J, Wang J, Ma Z, Han P, Luan Y, Lu A (2015) Occurrence of antibiotics in soils and manures from greenhouse vegetable production bases of Beijing, China and an associated risk assessment. Sci Total Environ 521522:101-107

Nowara A, Burhenne J, Spiteller M (1997) Binding of fluoroquinolone carboxylic acid derivatives to clay minerals. J Agric Food Chem 45(4):1459-1463

Rabùlle M, Spliid NH (2000) Sorption and mobility of metronidazole, olaquindox, oxytetracycline and tylosin in soil. Chemosphere 40:715-722.

Shi Y, Gao L, Li W, Liu J, Cai Y (2012). Investigation of fluoroquinolones, sulfonamides and macrolides in long-term wastewater irrigation soil in Tianjin, China. Bull Environ Contam Toxicol 89:857-861

Sim W-J, Lee J-W, Lee E-S, Shin S-K, Hwang S-R, Oh J-E (2011) Occurrence and distribution of pharmaceuticals in wastewater from households, livestock farms, hospitals and pharmaceutical manufactures. Chemosphere 82(2):179-186

Tokura Y, Nishijima T, Yagi H, Furukawa F, Takigawa M (1996) Photohaptenic properties of fluoroquinolones. Photochem Photobiol 64(5):838-844

United Nations, Department of Economic and Social Affairs, Population Division (2015) World population prospects: the 2015 revision, key findings and advance tables. Working Paper No. ESA/P/WP.241

Van Boeckel TP, Gandra S, Ashok A, Caudron Q, Grenfell BT, Levin SA, Laxminarayan R (2015) Global antibiotic consumption 2000 to 2010: an analysis of national pharmaceutical sales data. Lancet Infect Dis 14(8):742-750

Watkinson AJ, Murby EJ, Costanzo SD (2007) Removal of antibiotics in conventional and advanced wastewater treatment: Implications for environmental discharge and wastewater recycling. Water Res 41(18):4164-4176 
The page numbers of the chapter has been updated to 39-54

Chapter 4: Entry Routes of Veterinary Antibiotics in the Environment The page numbers of the chapter has been updated to 55-70

Chapter 5: Monitoring of Antibiotics and Antibiotic Resistance Genes in Agroecosystems

The page numbers of the chapter has been updated to 71-96

Chapter 6: Role of Antibiotics in Climate Change

The page numbers of the chapter has been updated to 97-104

Chapter 7: Potential Dissemination of ARB and ARGs into Soil Through the Use of Treated Wastewater for Agricultural Irrigation: Is It a True Cause for Concern?

The page numbers of the chapter has been updated to 105-140

Chapter 8: Antibiotic Resistance Gene Due to Manure Application

The page numbers of the chapter has been updated to 141-150

Chapter 9: Antibiotics and Antibiotics Resistance Genes Dissemination in Soils The page numbers of the chapter has been updated to 151-190

Chapter 10: Dissemination Mechanism of Antibiotic Resistance Genes in Environment

The page numbers of the chapter has been updated to 191-206

Chapter 11: Fate of Antibiotics in Soil

The page numbers of the chapter has been updated to 207-220

Chapter 12: Uptake of Antibiotics by Plants

The page numbers of the chapter has been updated to 221-238

Chapter 13: Recent Advances in Methods for the Detection of Antibiotics and Antibiotics Resistance Genes in Soil

The page numbers of the chapter has been updated to 239-258

Chapter 14: Elucidation of Emerging Nanomaterials Impacts on Antibiotic Resistance Against Soil and Aquatic Microflora

The page numbers of the chapter has been updated to 259-282

Chapter 15: The Effects of Antibiotics on the Structure, Diversity, and Function of a Soil Microbial Community

The page numbers of the chapter has been updated to 283-312 
Chapter 16: Soil Antibiotics and Transfer of Antibiotic Resistance Genes Affecting Wildlife

The affiliations of the following authors have been corrected and the correct affiliations are:

\section{Gilberto Igrejas}

Department of Genetics and Biotechnology, Functional Genomics and Proteomics' Unit, University of Trás-os-Montes and Alto Douro, Vila Real, Portugal

Functional Genomics and Proteomics Unit, University of Tras-os-Montes and Alto Douro (UTAD), Vila Real, Portugal

Research Unit on Applied Molecular Biosciences (UCIBIO-REQUIMTE), University NOVA of Lisboa, Lisboa, Caparica, Portugal

\section{Patrícia Poeta}

Veterinary Sciences Department, University of Trás-os-Montes and Alto Douro, Quinta de Prados, 5000-911 Vila Real, Portugal

Research Unit on Applied Molecular Biosciences (UCIBIO-REQUIMTE), University NOVA of Lisboa, Lisboa, Caparica, Portugal

The contents of the following sub-headings have been updated:

1) 16.2 Interaction of Antibiotics with Soil

2) 16.4 Antimicrobial Resistance in the Environment

3) 16.5 The Problem of Antibiotic Resistance in Wild Animals

The page numbers of the chapter has been updated to 313-326

Chapter 17: Genotoxicity and Biochemical Toxicity of Soil Antibiotics to Earthworms

The page numbers of the chapter has been updated to 327-340

Chapter 18: Potential Environmental, Ecological and Health Effects of Soil Antibiotics and ARGs

The page numbers of the chapter has been updated to 341-366

Chapter 19: Risk Assessment of Antibiotics and Antibiotic-Resistant Genes in Soil

The page numbers of the chapter has been updated to 367-386

Chapter 20: Antibiotics in the Soil: Sources, Environmental Issues, and Bioremediation

The page numbers of the chapter has been updated to 387-396 
Chapter 21: Management and Regulation of Antibiotics and Antibiotics Resistance Genes in Soils

The page numbers of the chapter has been updated to $397-410$

INDEX of the book has been updated.

The page numbers of the INDEX has been updated to 411-420 